\title{
New Middle Jurassic tangle-veined flies from Inner Mongolia, China
}

Kuiyan Zhang, Ding Yang, Dong Ren, and Fengchen Ge

Acta Palaeontologica Polonica 53 (1), 2008: 161-164 doi:http://dx.doi.org/10.4202/app.2008.0112

This is an open-access article distributed under the terms of the Creative Commons Attribution License (for details please see creativecommons.org), which permits unrestricted use, distribution, and reproduction in any medium, provided the original author and source are credited.

Fof 